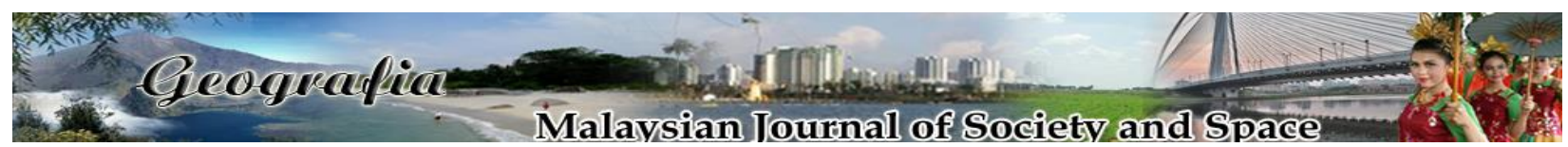

\title{
Demographic analysis towards the understanding of Education Takaful (Islamic Insurance) Plan
}

\author{
Rubayah Yakob, Hafizuddin-Syah B.A.M, Nurfarhana Hani Badrul Hisham \\ Governance, Resilience \& Accountability Center \\ Faculty of Economics and Management \\ Universiti Kebangsaan Malaysia \\ Malaysia
}

Correspondence: Hafizuddin-Syah B.A.M (m_hafiz@ukm.edu.my)

Received: 11 June 2019; Accepted: 21 October 2019; Published: 25 November 2019

\begin{abstract}
This study aims to identify the demographic characteristics affecting the level of understanding of education takaful plan. The data was collected through questionnaires from 145 respondents in Klang Valley, Malaysia, which chosen based on the convenience sampling technique. Results from the independent sample t-test and one-way ANOVA showed that female possess higher level of understanding of education takaful than male. Moreover, workers in the government sector have better understanding on education takaful as compared to self-employed and students. However, there are no significant differences on the understanding of education takaful between government and private sector. This study also found that those who have 1 to 3 children demonstrate higher understanding of education takaful. Overall, the employment sector and number of children had a significant influence on the understanding of education takaful. This study provides a preliminary overview of the demographic factors affecting the understanding of education takaful in Malaysia, which can be used by the takaful industry to strengthen and manage their product development and marketing strategies. It subsequently helps to achieve the target population penetration rate of $25 \%$ takaful ownership by 2020 .
\end{abstract}

Keywords: demographic, education, risk, takaful, understanding

\section{Introduction}

Higher education is important for any individual and often viewed as a stepping stone to secure better employment in the future. However, the cost of higher education in Malaysia is getting expensive (Morshidi Sirat, 2018) and can reach hundreds of thousands of Malaysian Ringgit (Zulita Mustafa, 2017). This situation had left many parents facing the problem in raising sufficient tertiary education fund for their children. The driving factors for this problem include 
the rising cost of living, increase in the education cost and the declining offering of government scholarship. Another factor of insufficient funding of children's education is the contingent risks such as pre-mature death, disability, and critical illness that may befall their parents. These risks disrupt the financial sustainability of a family when unforeseen events occur, especially to the breadwinner. Any saving that been made will be adversely affected if the breadwinner of the family suddenly passed away, become disable or afflicted with critical illnesses. As a result, the spouse and children left behind will highly expose to the risk of insufficient fund for living and lead to severe financial difficulties. Consequently, the education funds for the children to pursue higher education will be also affected.

Therefore, these contingent risks must be managed accordingly to minimize the negative impact. One of the systematic methods is the purchase of education takaful (Islamic insurance) plan. In particular, education takaful plan provides education funds and protection against premature death, disability and critical illness. In Malaysia, there are several education takaful plans such as Polisi Intelek, Pelan Pendidikan Takaful, HLM Takaful i-Grad, PruBSN SmartLink, Sun EduSmart and EduCAre-i Pendidikan. However, it remains an issue whether the parents are aware on the capabilities of education takaful plans in providing educations funds for their children. Statistics shows that only $14.66 \%$ Malaysians participated in family takaful plan (Malaysian Takaful Association, 2017). This shows that most Malaysians have yet to understand the importance and capability of takaful products in minimizing financial difficulties arisen from the contingent risks. Therefore, this study aims to evaluate the level of understanding on takaful plans specifically education takaful and identify the demographic characteristics that affect their level of understanding. In fact, studies on the understanding of insurance and takaful policies are limited in Malaysia, especially takaful education plans. Past studies have identified that understanding/knowledge of takaful as the determinants of takaful demand. However, the influence of demographic characteristics towards the level of takaful understanding remains ambiguous. Thus, the results of this study provide a preliminary overview on takaful understanding and the demographic characteristics that affect takaful understanding for the takaful industry in strengthening and managing their marketing and product development strategies. Moreover, it allows takaful operators to redesign their campaigns to enhance the takaful understanding by focusing on specific targets to increase parents' participation in takaful, particularly education takaful plan. This will in some ways aid the target penetration rate of $25 \%$ of the population owning takaful by 2020 .

\section{Literature review}

Takaful is an Islamic insurance in which each participant contributes funds into a pool of funds to help each participant against losses due to unexpected events. Islamic Financial Services Act 2013 (IFSA, 2013) defines takaful as "an arrangement based on mutual assistance under which takaful participants agree to contribute to a common fund providing for mutual financial benefits payable to the takaful participants or their beneficiaries on the occurrence of pre-agreed events". In other words, takaful allows participants to help or being helped by other participants. This concept is called as mutual protection and indemnity (Mohd Daud, 2009).

The objective of takaful and conventional is providing protection against risk exposure. However, the operation of takaful makes it differs from conventional insurance. Takaful contract is positioned based on the principle of joint guarantee. Through this principle, takaful operators 
act as a representative (wakeel) to manage the takaful operation such as underwriting, claims and investment (Mohd Daud, 2009). On the other hand, insurance company guarantees to pay a compensation if the stipulated event in the contract occurred, in exchange to the premium paid by insured (International Shariah Research Academic for Islamic Finance, 2011). Furthermore, contribution by participant is belong to the participant and takaful operator helps to manage this takaful fund. In contrast, premium paid by insured is belong to the insurance company and possess the right on the insurance pool. The comprehensive differences between takaful and conventional insurance are shown in Table 1.

Table 1. The differences between takaful and conventional insurance

\begin{tabular}{l} 
Takaful \\
\hline A combination of tabarru' contract and agency and/ or \\
profit sharing contract \\
Participants are duty-bounded to make contributions to \\
the scheme and expected to mutually share the surplus \\
Takaful operator earns a return for rendering a service \\
managing the takaful programme and from the \\
mudharabah profit sharing scheme as mudarib \\
Counter-value ('iwad) is effort and/ or undertaking of \\
risk
\end{tabular}
risk

Takaful operators acts as administrator of the takaful fund and pays benefits for it. Any insufficiency in the fund will be rectified by the takaful operator via interestfree loans.

Indemnification component is based on mutual contribution, reciprocal donation (tabarru')

There is no insurer-insured relationship between takaful operator and participants. Participants act as both insured and the insurer simultaneously

Takaful fund must be invested in Shariah-complaint instruments

Source: International Shariah Research Academic for Islamic Finance, 2011

Generally, takaful education plan could act as a scholarship fund to finance the higher education of children in the future. These plans encourage parental savings and protect themselves against personal risk. Jamaldeen (2012) defines takaful education plan as a plan that promotes savings for the future needs of children's education and protection against the risk of disability, death or critical illness during the takaful contract period. If these risks occur to the participant, takaful operators will contribute fund for the remaining contract period covered to fulfill the takaful plan's goal i.e. accumulation of fund for future education. In Malaysia for instance, Ikhlas Education Takaful by Syarikat Takaful Ikhlas Sdn Bhd provides a long term protection needs and future education savings for children aged 30 days up to 12 years. In addition, some education plans such Intelek from Etiqa Takaful Berhad provides rewards for children on their outstanding achievements. Historically, various innovations and development of takaful products have been carried out since its inception in 1984 to stimulate the growth and 
demand for takaful plans. However, participation in takaful products remains undesirable. In 2017, only 14.66\% of Malaysians were protected by family takaful plans (Malaysian Takaful Association, 2017). Furthermore, the Malaysian Takaful Association in BHonline (26 October 2018) cites that as of August 2018, the family takaful penetration rate is $15 \%$. Whereas, the overall takaful and insurance participation is about 56, which leave $44 \%$ of Malaysians without any life insurance or family takaful protection. According to Hendon et al. (2016), the amount of protection for those who have life insurance policies is insufficient. In fact, Hendon et al. (2016) also found that on average each insured household in Malaysia is insufficiently protected by approximately RM500, 000.

Meanwhile, Norashikin et al. (2012) suggest that lack of understanding and awareness of the takaful products lead to low takaful demand. Consistently, Noor Ashikin \& Zuriah (2012) show that $97 \%$ of respondents do not know about takaful or insurance protection. Accordingly, the CEO of Etiqa Takaful Bhd has highlighted the lack of awareness of the importance of insurance or takaful among Bumiputera in Malaysia (MStar, 2014). In fact, takaful agents also believed that the public's understanding and awareness aspects drive for low participation in takaful products among the public (Izzati Liyana \& Hendon, 2015). Yon Bahiyah et al. (2009) stressed that the awareness and understanding of the Malay community can be enhanced through aggressive promotion from authorities and industry to promote Islamic finance. In addition, takaful agents, friends, family and print media also play an important role in increasing public understanding of takaful (Mohamad \& Mohd Sukki, 2009). Indeed, Izzati Liyana \& Hendon (2015) suggested that religious factors were associated with the level of takaful awareness. They also found that non-Muslim students were aware of the existence of takaful but do not know the concept of takaful and do not realize that takaful is meant for all individuals.

In addition, Kamarul et al. (2015) stressed that religious factors played a significant influence on the ownership of takaful plans and Muslims preferred takaful plans rather than conventional insurance. Similarly, Gustina \& Nurdianawati (2012) demonstrated that the Muslim community in Malaysia believes that takaful products are better than conventional insurance in terms of prices and benefits. However, Asmak et al. (2008) shows that religious factors have no effect on the demand for takaful plans. In fact, the respondents prefer conventional insurance due to their perception that conventional insurance is superior in all aspects as compared to takaful plans.

In the meantime, Zuriah et al. (2008) found that Malaysian society have very high awareness on takaful products and its benefits. Unfortunately, insufficient income hinders them from owning a takaful plan. Apparently, family takaful plan may only be considered after other necessities have been fulfilled. In contrast, some studies found that income has a significant positive relationship with family takaful ownership in Malaysia (Sherif \& Nor Azlina, 2013; Rubayah \& Nor Hamizah, 2017). Moreover, Noor Ashikin \& Zuriah (2012) suggested that most respondents were able to contribute the minimum amount required for protection. In fact, an increase of $10 \%$ in income would increase the purchase of life insurance by $63 \%$ and family takaful by $45 \%$ (Hendon, 2014).

In addition, Hendon (2014) also demonstrated that the number of dependents and education levels were important determinants of life insurance and family takaful demand in Malaysia. These findings were consistent with Nurul \& Sarah (2013) in their study on the factor of life insurance purchase in Kuala Lumpur. However, the number of family members does not affect the purchase of life insurance in Croatia (Ćurak et al., 2013). Meanwhile, Puspa Liza et al. (2012) claimed that the price and benefits of education takaful plan also affect the demand of this plan. Furthermore, if the education plan offered reasonable price and riders, all income levels 
could afford to own it. In other study, Zainudin et al. (2016) found that the savings element in the family takaful plan had a dominant influence in establishing takaful purchase intentions. However, Yon Bahiyah et al. (2009) highlighted that protection element is more important.

Awareness on takaful plans is a global issue and has attracted interest from international researcher. Sutan \& Ameena (2014) found that the level of education affects the level of awareness of takaful plans in Bahrain. It shows that those with higher education levels possess higher awareness on terms, principles, concepts and models in takaful operations. In Kuwait, women were found to have higher knowledge about takaful plans than men, while those working in the private sector generally possess higher knowledge on takaful plan (Soualhi \& Al Shammari, 2015). AlNemer (2015) found that the level of awareness and understanding among respondents in Saudi Arabia is still low. However, 64\% of respondents in Pakistan were aware of the basic concepts of takaful, while majority of respondents have knowledge of takaful principles and interests (Malik et al., 2012). According to study by Sinha et al. (2011), individuals' awareness towards insurance in India varies by location, type of policy, state and level of education. Understanding level for individuals in the cities were higher than those in rural areas. Moreover, the knowledge about life insurance is far better than health insurance. This study concluded that education was an important factor in influencing the awareness of rights and responsibilities as a policyholder. Awareness also varies between insured and uninsured individuals. However, this study did not prove the relationship through empirical analysis. Moreover, demographics and knowledge were significantly related with micro life insurance awareness among hawkers in Bangladesh (Manik \& Abdul Mannan, 2017). The demographic variables include gender, income, and type of business, while knowledge categorized into knowledge on policies, products, financial security and financial benefits of life insurance. Yellaiah (2012) also found that level of education, annual income, employment, religion and family type significantly affect health insurance awareness. Meanwhile, studies in Indonesia observed that only $49.5 \%$ of respondents were aware about life insurance (Sri Hermawati, 2011).

Overall, most of the previous studies focused on the awareness and understanding of family takaful plans in general. However, studies on a specific takaful product i.e. education plans are rather limited. Furthermore, analysis on the understanding of takaful across demographics has not been entirely explored. Therefore, the examination on the level of understanding towards education takaful and demographic factors associated to the level of understanding should be carried out. It provides initial inputs and insight for regulators and industry players in enhancing participation in education takaful plans.

\section{Methodology}

\section{Sample and Data}

The sample of this study consists of respondents around Klang Valley, which is the most populated area in Malaysia (Department of Statistics Malaysia, 2016) with a population of $7,642,100$. However, as a preliminary study, only 145 respondents were taken using convenience sampling method. This method refers to the collection of information from members in an easily accessible population (Sekaran \& Bougie, 2016). Furthermore, convenience sampling method is the most suitable and accurate way to obtain information in a quick and easy manner. 
The data were obtained through questionnaires. This study has adapted a questionnaire from the National Council of Applied Economic Research-NCAER (Sinha et al., 2011), which evaluated the public awareness of insurance protection in India. Thus, few aspects of Sinha et al. (2011) questionnaire had been modified to fulfill the context of takaful plan. The questionnaire is divided into two parts, part A and B. Part A comprises demographic information such as gender, age, education level, employment, monthly income and number of children. Each question in this section is a closed question in which respondents are given a choice of specific answers. Meanwhile, Part B focuses on the questions related to the four components of education takaful understanding namely concept, importance, protection and benefits. A total of thirty-one questions in Part B; six questions each for the concept and importance, twelve questions for protection and seven questions for the benefit (Table 2). The answer format in Section B uses 5point Likert Scale ( $1=$ strongly disagree to $5=$ strongly agree)

Table 2. Numbers of items for each component

\begin{tabular}{cc}
\hline Understanding component & Number of items \\
\hline Concept & 6 \\
Importance & 6 \\
Protection & 12 \\
Benefit & 7 \\
\hline
\end{tabular}

\section{Data analysis method}

Respondent's understanding level is categorized into three, namely low, medium and high. Following Mohamad Idham et al. (2014), the range of each level can be calculated by adding the minimum value of each level with the average range (the ratio between the width of the Likert Scale used and the number of desired levels of understanding). This study employs 5-point Likert Scale with the minimum value of 1 and a maximum value of 5; and the desired category of understanding is 3 . Therefore, the average range for each level of understanding required is:

$$
\text { Average range }=(5-1) / 3=1.33
$$

Summary of level of understanding is shown in Table 3. However, to ensure the consistency across items in the same component, the reliability test is carried out beforehand.

Table 3. Level of awareness

\begin{tabular}{ccc}
\hline Level of understanding & Range calculation & Range mean \\
\hline Low & $1+1.33=2.33$ & $1-2.33$ \\
Medium & $2.34+1.33=3.67$ & $2.34-3.67$ \\
High & $3.67+1.33=5.0$ & $3.68-5.0$ \\
\hline
\end{tabular}

Source: Mohamad Idham et al. (2014)

Independent sample t-test and one-way ANOVA test

In determining the demographic factors that affect the level of understanding of the education takaful plan, this study uses independent sample t-test and one-way ANOVA test. Through this test, the differences in overall understanding between different groups for each demographic 
feature can be measured. Specifically, independent sample t-tests were performed to determine the difference in the average score of a continuous variable (level of understanding), for groups with two categories (Sekaran \& Bougie, 2016). The hypothesis for independent sample t-test is as follows:

$$
H_{0}: \mu_{1}=\mu_{2}
$$

where, $\mu_{1}$ and $\mu_{2}$ are the average value of the first and second category, respectively. This study tested the influence of gender on understanding with a t-test using the following null hypothesis:

$\mathrm{H}_{01}$ : There is no significant difference in understanding between genders.

Meanwhile, one-way ANOVA test determines the difference in the average score of a continuous variable (level of understanding) for groups with more than two categories (Sekaran \& Bougie, 2016). The hypothesis of the one-way ANOVA test is as follows:

$$
H_{0}: \mu_{1}=\mu_{2}=\ldots=\mu_{k}
$$

where, $\mu$ is the average value for a category and $k$ is the number of categories. However, oneway ANOVA test gave an overall effect between independent variable and dependent variable (omnibus statistics) which is at least 2 categories with a significant difference. Therefore, the actual category that is different cannot be identified using the one-way ANOVA test. For this purpose, post-hoc test needs to be carried out. Other variables such as age, education level, employment, income and number of children were tested using ANOVA with null hypotheses as follows:

$\mathrm{H}_{02}$ : There is no significant difference in understanding between age categories.

$\mathrm{H}_{03}$ : There is no significant difference in understanding between education levels. $\mathrm{H}_{04}$ : There is no significant difference in understanding between employment sectors. $\mathrm{H}_{05}$ : There is no significant difference in understanding between income categories. $\mathrm{H}_{06}$ : There is no significant difference in understanding between numbers of children.

If the results for both independent sample t-test and one-way ANOVA test are statistically significant, the null hypothesis is rejected. It infers the existence of a significant difference in average between the categories observed.

\section{Study findings}

\section{Descriptive analysis}

Table 4 showed that $53.1 \%$ of respondents were female, while male represents $46.9 \%$. Age distribution demonstrated that most of respondents were below 40 years $(53.8 \%)$ and only $3.4 \%$ aged above 60 years. Additionally, $41.4 \%$ of the respondents hold Sijil Pelajaran Malaysia (SPM), while $10.3 \%$ and $25.5 \%$ possess Diploma and Bachelor Degree respectively. Other education qualifications were below $10 \%$. For employment, $37.9 \%$ were working in the government sector while $32.4 \%$ in the private sectors. The remaining were self-employed, 
students and other category i.e. pensioners and housewives. Apparently, majority of respondents had a monthly income of RM4000 and below (79.3\%), while only $20.7 \%$ earns more than RM4000 a month. More than $44 \%$ of the respondents had 1 to 3 children, $26.9 \%$ with 4-6 children, $8.3 \%$ had more than 6 children while $20 \%$ had no children.

Table 4. Distribution of demographic characteristics

\begin{tabular}{|c|c|c|c|}
\hline & $\begin{array}{l}\text { Demographic } \\
\text { characteristics }\end{array}$ & Frequency & Percentage (\%) \\
\hline \multirow{2}{*}{ Gender } & Male & 68 & 46.9 \\
\hline & Female & 77 & 53.1 \\
\hline \multirow[t]{5}{*}{ Age (Years) } & $20-29$ & 33 & 22.8 \\
\hline & $30-39$ & 45 & 31.0 \\
\hline & $40-49$ & 26 & 17.9 \\
\hline & $50-59$ & 36 & 24.8 \\
\hline & 60 and above & 5 & 3.4 \\
\hline \multirow{7}{*}{ Education level } & $<=$ Primary school & 11 & 7.6 \\
\hline & Certificate/SPM & 60 & 41.4 \\
\hline & STPM & 12 & 8.0 \\
\hline & Diploma & 15 & 10.3 \\
\hline & Bachelor Degree & 37 & 25.5 \\
\hline & Master Degree & 8 & 6.0 \\
\hline & Doctor of Philosophy & 2 & 1.0 \\
\hline \multirow[t]{5}{*}{ Employment } & Government & 55 & 37.9 \\
\hline & Private & 47 & 32.4 \\
\hline & Self-employed & 18 & 12.4 \\
\hline & Studying & 9 & 6.2 \\
\hline & Others & 16 & 11.0 \\
\hline \multirow{5}{*}{ Income (RM) } & $<=1,000$ & 27 & 18.6 \\
\hline & $1,001-2500$ & 37 & 25.5 \\
\hline & $2,501-4,000$ & 51 & 35.2 \\
\hline & $4,001-5,500$ & 15 & 10.3 \\
\hline & $5,501=>$ & 15 & 10.3 \\
\hline \multirow{4}{*}{ Number of children } & None & 29 & 20.0 \\
\hline & $1-3$ & 65 & 44.8 \\
\hline & $4-6$ & 39 & 26.9 \\
\hline & $>6$ & 12 & 8.3 \\
\hline
\end{tabular}

\section{Level of understanding}

Table 5 showed the reliability test results of the items used to measure each component of takaful education understanding. The coefficients of Cronbach's Alpha for concept, importance, protection, and benefit were $0.86,0.84,0.90$ and 0.90 respectively. These values were more than the acceptable reliability value of 0.7 (Sekaran \& Bougie, 2016). Therefore, these items measure the same components (in their respective components) and have a high correlation between each other. 
Table 5. Reliability test results

\begin{tabular}{cc}
\hline Understanding component & Cronbach's Alpha Coefficient \\
\hline Concept & 0.86 \\
Importance & 0.84 \\
Protection & 0.90 \\
Benefit & 0.90 \\
\hline
\end{tabular}

Based on Table 6, the mean value of each component of understanding i.e. concept, importance, protection and benefit were 3.88, 3.76, 3.86 and 3.71 respectively. It illustrates that the level of understanding on the concept, importance, protection, and benefit of education takaful among respondents was high (see Table 3). Finally, the overall mean value of understanding is relatively high, stood at 3.80.

Table 6. Mean score of understanding component

\begin{tabular}{clc}
\hline No. & Variable & Average \\
\hline 1 & Education takaful concept & 3.88 \\
2 & Importance of education policy & 3.76 \\
3 & Protection under the policy & 3.86 \\
4 & Benefits under the policy & 3.71 \\
5 & Average overall understanding & 3.80 \\
\hline
\end{tabular}

\section{Profile of education takaful understanding}

Table 7 illustrated the average mean score of understanding across demographics such as gender, age, education level, employment sector, income and number of children. Female has higher level of understanding than male, as shown by the mean score of 3.88 over 3.71. Meanwhile, the group age between 30 and 40 years have the highest mean score of 3.88, while those aged 60 years and above score lowest mean. It showed that child education cost is no longer relevant as age increases, hence lessen the importance of understanding towards education takaful plan. For education level, those who possess Doctor of Philosophy score the highest level of understanding, whilst primary school and below showed the lowest score.

Moreover, the average understanding among working individuals in the government sector (3.89) was higher than other sectors such as private sector (3.86) and self-employed (3.60). Individuals with more than RM5,000 monthly incomes also score the highest level of understanding at 3.96 compared to other salary intervals. Additionally, outputs from Table 7 also suggest that the mean score of understanding decrease as number of children increases. Interestingly, the level of understanding among individuals without children is quite high at 3.68. These findings were somehow consistent with previous studies such as Manik \& Abdul Mannan (2017), Yellaiah (2012) and Sinha et al. (2011). For instance, Yellaiah (2012) found the existence of difference in percentages for health insurance awareness across gender, age, religion, education level, employment sector and family type. 
Table 7. Descriptive analysis of average understanding across demographics

\begin{tabular}{llc}
\hline & Demographic feature & Understanding level \\
\hline Gender & Male & 3.71 \\
Female & Years) & 3.89 \\
& $30-39$ & 3.67 \\
Education level & $40-49$ & 3.87 \\
& $50-59$ & 3.88 \\
& 60 and above & 3.80 \\
& <=Primary school & 3.60 \\
& Certificate/SPM & 3.72 \\
STPM & 3.82 \\
Employment & Diploma & 3.91 \\
& Bachelor Degree & 3.89 \\
& Master Degree & 3.77 \\
& Doctor of Philosophy & 3.77 \\
& Government & 4.08 \\
& Private & 3.89 \\
& Self-employed & 3.86 \\
& Studying & 3.60 \\
Oncome (RM) & Others & 3.50 \\
& $<=1,000$ & 3.72 \\
& $1,001-2,500$ & 3.66 \\
& $2,501-4,000$ & 3.75 \\
& $4,001-5,500$ & 3.87 \\
& $5,501=>$ & 3.76 \\
& None & 3.96 \\
& $1-3$ & 3.68 \\
& $4-6$ & 3.88 \\
& $>6$ & 3.84 \\
& & 3.54 \\
\hline
\end{tabular}

The Findings from independent sample t-test and one-way ANOVA Test

T-test result in Table 8 showed that gender is significantly affects the understanding of education takaful plan, at $\alpha=0.05$. It indicates the existence of difference in the level of understanding of education takaful plans between female and male. Specifically, female has higher level of understanding (3.88) than men (3.71), which consistent with Soualhi \& Al Shammari (2015). In fact, women are naturally more concerned and more mindful, which lead to higher understanding of takaful plans than men. However, gender was not significant in determining micro life insurance awareness among Indian hawkers (Manik \& Abdul Mannan, 2017).

Table 8. T-test results

\begin{tabular}{ccc}
\hline Demographic characteristic & t-statistic & $\boldsymbol{\rho}$-sign \\
\hline Gender & -2.082 & $0.037^{*}$ \\
\hline Notes:* significant at $\alpha=0.05$ & &
\end{tabular}


Meanwhile, the results of the one-way ANOVA test in Table 9 proved that the employment sector and number of children have significantly influence the understanding of education takaful, at $\alpha=0.1$

Table 9. One-way ANOVA test results

\begin{tabular}{ccc}
\hline Demographic feature & F-statistic & $\boldsymbol{\rho}$-sign \\
\hline Age & 1.097 & 0.360 \\
Education level & 0.701 & 0.649 \\
Employment & 2.168 & $0.076^{*}$ \\
Income & 1.266 & 0.286 \\
Number of children & 2.181 & $0.093^{*}$ \\
\hline
\end{tabular}

Notes:* significant at $\alpha=0.1$

In detail, the understanding of takaful education between those who work in the government sector is significantly different, at $\alpha=0.05$ with those who self-employed $(\rho=0.049)$ and students $(\rho=0.026)$. Furthermore, the understanding among individuals in private sector is also significantly differed with student $(\rho=0.041)$. Specifically, individuals who working in government sector have a significantly higher level of understanding (3.89) compared to selfemployed individuals (3.60) and students (3.50). Likewise, individuals in the private sector are also found to have a significantly higher level of understanding (3.86) compared to students (3.50). These results were consistent with Soualhi \& Al Shammari (2015) and Yellaiah (2012). In fact, civil servants in Malaysia have been more exposed to takaful plans in recent years after the inception of Cuepac-Care. Cuepac-Care is a specific takaful plan for Malaysian civil servants to cater their need for takaful protection. Perhaps, it indirectly improved the understanding of takaful concept and its importance among civil servants. Indeed, the exposure on takaful concept and benefits is higher in private sector which lead higher level of understanding compared to students. However, the level of understanding among civil servants and private sector workers was not significantly different. Its contradicted to Soualhi \& Al Shammari (2015), who found that private sector workers were generally possess higher knowledge on takaful plans than other sectors.

In terms of the number of children, individuals who had between 1-3 children score the highest level of understanding (3.88) and significantly different from those who had no children (3.68) and more than 6 children (3.54) at $\alpha=0.1$ and $\alpha=0.05$. It indicated the existence of a trend in understanding distribution, with level of understanding was low at both extreme numbers of children as compared to individuals with 1-3 children. For individuals without children, the necessity to purchase education takaful might not exist, which detach their need to further understand the education takaful plan. Perhaps, the understanding towards other types of takaful plans is more preferred. Meanwhile, for individuals with over 6 children, the understanding of education takaful is relatively low as compared to individuals with 1-3 children because of the shift in priority to a comprehensive family takaful plan rather than a specific education takaful for each child. In fact, other expenses for the whole family also need to be considered. In general, these findings support Noor Ashikin \& Zuriah (2012) and Nurul \& Sarah (2013) but contradicted to findings by Ćurak et al. (2013) and Yellaiah (2012).

In addition, the understanding of education takaful is not significantly different in age, education and income levels. This finding consistent to Hussein \& Al Anood (2009), who found the insignificant difference in financial literacy across different levels of income and age of purchasers in the UAE, but it was the opposite result for the level of education. However, Manik 
\& Abdul Mannan (2017) and Yellaiah (2012) report different results, as knowledge or education level and income has played an important role in insurance awareness.

\section{Conclusion}

This study found that the understanding level on education takaful among respondents in Klang Valley is high. However, there is still room to thoroughly improve the public's understanding on takaful education plan to overcome their hesitation in purchasing education takaful plans. Takaful operators can work together with employers or authorities to promote education plan. In fact, it must be given priority by parents and becomes an intergal agenda in family financial management.

Additionally, the exposure on the takaful needs to be addressed by the industry based on demographic profiles, including gender, employment, and number of children. It is worth to highlight that female has higher knowledge on education takaful compared to their male counterpart. As male remains as a dominant breadwinner in Malaysia and more vulnerable to personal risks such death, disability and critical illness, the necessity for in-depth understanding on the importance of education takaful is more demanding for male. In fact, higher understanding could lead to higher education takaful ownership and subsequently sustain their children future education fund.

Furthermore, those who work in the government or private sector tend to have higher exposure on takaful protection. In fact, their organizations might offer takaful protection such as group takaful. However, low ownership of insurance and takaful among self-employed individuals and students may be associated to the lack of exposure. For students, the necessity to own an education takaful at this stage might be perceived as unimportant. However, the understanding on takaful education is crucial at the early stage (e.g. university's students) to ensure they are able manage any financial impact due to unforeseen events. This study also suggests that the understanding of education takaful among individuals with many children also needs to be improved. Generally, education takaful is essentially needed by individuals with more children as its guarantee education funding for children in the event of an undesired mishap befalls the head of the family.

Hence, the industry and authorities should work together to enhance the public understanding towards education takaful by considering the demographic characteristics that have been identified in this study. Indeed, it could assist to formulate marketing strategies to reach the right target market. Most importantly, every family in Malaysia should consider an education takaful as integral part of their financial planning to sustain their children's future education fund. It subsequently helps towards achieving the target population penetration rate of $25 \%$ takaful ownership by 2020.

\section{Acknowledgement and appreciation}

This study is funded by Initiative Grant, Faculty of Economics and Management, Universiti Kebangsaan Malaysia (EP-2017-043). 


\section{References}

AlNemer, H. (2015). Participants' knowledge and Educational Background about Takaful Products \& Services. An Empirical Study on Saudi Arabia. International Journal of Business, Economics and Law, 7(1), 43-53

Asmak, A.R., Azizi, C.S., \& Wan Marhaini, W.A. (2008). Comparative Study Between Auto Takaful and Auto Insurance Purchasing Behaviour among Malaysian Undergraduates, Shariah Journal, 6(1), 75-88

Ćurak, M., Dźaja, I., \& Pepur, S. (2013). The Effect of Social and Demographic Factors on Life Insurance Demand in Croatia International Journal of Business and Social Science, 4(9), 6572.

Gustina \& Nurdianawati, A. (2012). Analysis of Demand for Family Takaful and Life Insurance: A Comparative Study in Malaysia. Journal of Islamic Economics, Banking and Finance, $8(4)$.

Hendon, R. (2014). Analysis Of The Demand For Life Insurance and Family Takaful. Proceedings of the Australian Academy of Business and Social Sciences Conference, 1-16.

Hendon, R., Rubayah, Y., \& Zaidi, I. (2016). Underinsurance in Malaysia: The application of the Monte Carlo simulation. Jurnal Pengurusan, 47, 131-141.

Hussein, A.A. \& Al Anood, K. (2009). Financial Literacy and investment decisions of UAE investors. Journal of Risk Finance, 10(5), 500-516.

International Shariah Research Academic for Islamic Finance (ISRA). (2011). Islamic financial system: principles and operations. Kuala Lumpur, International Shariah Research Academic for Islamic Finance.

Izzati Liyana, A., \& Hendon, R. (2015). Persepsi Pelajar Bukan Islam Terhadap Takaful. Jurnal Personalia Pelajar, 1-13.

Jamaldeen, F. (2012). Islamic Finance For Dummies. New Jersey, John Wiley \& Sons, Inc.

Kamarul, A.M., Raden, M.N.M., Masilah, M., \& Nursidrah, Z. (2015). A study on factor influencing Muslim's consumers preferences towards takaful products in Malaysia. Romanian Statistical Review, 63(2), 78-89.

Malaysian Takaful Association. (2017). Laporan Tahunan 2017. Retrieved from http://www.malaysiantakaful.com.my/ConsumerZone/Library/AnnualReport/News/AnnualReport-2017.aspx

Malik, M.I., Majeed, U.K., Shaukat, A., \& Shughla, Q. (2012). Customers' Preferences and Awareness Towards Takaful Coverage In Pakistan. SSRN Electronic Journal.

Manik, E.A. \& Abdul Mannan. (2017). An Investigation of the Awareness of the Life Insurance Among the Hawkers in Dhaka City: The Prospects of Microinsurance. European Journal of Business and Management, 9(2): 82-95.

Mohamad Idham, M.R., Siti Hawa, K., Raihan, M.G., Paramasivan S., \& De Mello, G.J.P. (2014). An overview of demand of life insurance in Malaysia. International Journal of Humanities and Social Science, 4(4), 244-250.

Mohamad, A.H., \& Mohd Sukki, O. (2009). A study on the level of knowledge and understanding among Muslims towards the concepts, Arabic and Shariah terms in Islamic Insurance (takaful). European Journal of social sciences, 10(3), 468-478.

Mohd Daud, B. (2009). Shari'ah Principles Governing Takaful Models. Takaful Islamic Insurance: Concepts and Regulatory Issues (pp. 31-46). Singapore, John Wiley \& Sons. 
Morshidi Sirat. (2018). Education costs rising. Retrieved from https://www.nst.com.my/opinion/letters/2018/07/391507/education-costs-rising

MStar. (2014). Industri Insurans Malaysia Dijangka Kukuh Tahun Depan. Retrieved from https://www.mstar.com.my/niaga/2014/12/26/industri-insurans

Norashikin, I., Alhabshi, S.O., \& Bacha, O.I. (2012). An analysis of cost efficiency in the Malaysian takaful industry. Insurance and Takaful Journal,2, 5-13.

Noor Ashikin, M.R., \& Zuriah, A.R. (2012). Financial Protection for the Poor in Malaysia: Role of Zakah and Micro-takaful. JKAU: Islamic Econ, 25(1), 119-140.

Nurul, S.M., \& Sarah, M.P.V. (2013). The determinants of life insurance demand: A focus on saving motives and financial literacy. Asian Social Science, 9(5), 274-284.

Puspa Liza, G., Ismail, M., Mustafa, M., \& Wan Muhamad, A.A. (2012). Integration Model of Education Plan Takaful: A Case Study for Terengganu, Kelantan and Perlis, States in Malaysia. Far East. Journal of Mathematical Sciences (FJMS), 65(1), 97-117.

Rubayah, Y., \& Nor Hamizah, A.R. (2017). Analisis Pemilikan Takaful Keluarga atau Insurans Hayat Dalam Kalangan B40. Journal of Quality Measurement and Analysis, 13(2), 29-38.

Sekaran, U., \& Bougie, R. (2016). Research Methods for Business: A Skill Building Approach. ( $7^{\text {th }}$ ed.). United Kingdom, John Wiley \& Sons, Inc.

Sherif, M. \& Nor Azlina, S. (2013). Determinants of demand on family Takaful in Malaysia. Journal of Islamic Accounting and Business Research, 4(1), 26-50.

Sinha, A., Jaiswal, R., Pal, B.D., \& Shuk, K. (2011). Pre-launch Survey Report of Insurance Awareness Campaign. India, National Council of Applied Economic Research.

Soualhi, Y., \& Al Shammari, A.A.R. (2015). Indicators of Takaful Awareness among Kuwaitis. Journal of Islamic Banking and Finance, 3(2), 75-89.

Sri Hermawati. (2011). Kesadaran Masyarakat Indonesia Akan Asuransi Jiwa. Skripsi Program Studi Akuntansi.

Sutan, E.H., \& Ameena, M.R. (2014). Public Awareness towards Takaful Concept and Principles: A Survey in Bahrai. International Journal of Excellence in Islamic Banking and Finance, 4(2), 1-16.

Yellaiah, J. (2012), Awareness of Health Insurance in Andhra Pradesh. International Journal of Scientific and Research Publications, 6(2), 1-6.

Yon Bahiyah, W.A., Siti Zaleha \& Norshahida, S. (2009). A Relook into Awareness, Perceptions, Barriers and Future Insurance needs: A Case Study of Takaful and the Malays. Conference of the International Journal of Arts and Sciences, 1(19), 10-21.

Zainudin, Z., Nurul Marina, Nik Fakrul, Wan Anisabanum, S., Mohd Tajul, Nur Raihana, M.S. \& Jannah Munirah, M. N. (2016). The Intention to Purchase Life Insurance: A Case Study of Staff in Public Universities. Procedia Economics and Finance, 37, 358 - 365

Zulita Mustafa. (2017). How much would it cost to pursue higher education in Malaysia? Retrieved from https://www.nst.com.my/news/2017/03/223461/how-much-would-it-costpursue-higher-education-malaysia

Zuriah, A.R., Rosylin, M.Y., \& Faizah, A. (2008). Family Takaful: It's Role In Social Economic Development and as a Savings And Investment Instrument In Malaysia. Jurnal Syariah, 16(1), 89-105. 